\title{
THE IMPACT OF INFORMATION TECHNOLOGY ON STUDENT'S ACHIEVEMENT AT THE UNIVERSITY OF FLORES IN THE CONTEXT OF SOCIO-CULTURAL RESILIENCE
}

\author{
Anastasia Mude ${ }^{1,}$ Kristina Sara ${ }^{2}$ \\ ${ }^{1,2}$ Information system, The University of Flores \\ Corresponding author: annmude87@gmail.com
}

\begin{tabular}{ll}
\hline Article Info \\
\hline Received $: 19$ August 2020 \\
Accepted $: 18$ September 2020 \\
Published : 22 October 2020
\end{tabular}

\begin{abstract}
This research aims to know the impacts between moral behavior, interaction with the community, and the impact of technology on Education which is the achievement index in Flores University especially in the study program of Accountant, management, Development Economics, and Information System. This research used the survey research approach with 95 respondents of the research sample. The method of analyzing data in this research was the correlation of Pearson Product Moment. To test the relation of some variables that used SPSS. The results of this research were: (1) The variable impact of Information systems on education had a positive impact on the achievement variable. (2) The interaction variable with the community did not have any impacts or influences on the achievement variable. (3) The moral behavior variable did not impact the achievement variable. It means that the use of good and right information technology will increase the students learning achievements, meanwhile the interaction with the community, and the moral behavior as the complement to support the students' success in gaining the good achievements in the University of Flores.
\end{abstract}

Keywords: Information

Technology, Interaction, Moral Behavior, Achievement.

\section{INTRODUCTION}

The information technology development is something unavoidable in this life because the progress of information technology goes according to the progress of Science. Information technology will continue to evolve because of human nature that is never satisfied with what they have now. All innovations are created to bring a positive influence on human life. Humans can already receive and enjoy the advantages of information technology development. 
This is supported by an opinion from Alter (1992) who defines that information technology includes hardware and software to do one or more tasks of data processing such as catching, transmitting, saving, taking, manipulating, or showing the data (Abdul Kadir, 2014). According to Martin (1999), information technology is not only limited to computer technology (hardware and software) that will be used to process and save the information but also includes the communication technology to send information (Abdul Kadir, 2014). Generally, Lucas (2000) stated that information technology is all forms of technology that are applied for processing and sending information (Abdul Kadir, 2014).

From the rapid development of information technology, people rapidly gain from all around the world too. The development does not change the world paradigms but also changes the human mindset and behavior. This change causes a big impact on the transformation of socio-culture values in the community.

The impacts of information technology development are also felt by the students from four study programs at Flores University such as the study program of information technology, management, development economics, and accounting. The progress of information technology surely becomes God that helps in gaining much information and science. But human/we cannot deceive our selves, that the progress of information technology has occurred negative impacts. Moreover, the information technology development has enslaved and exploited the privation of information technology user.

This research is about the impacts of information technology on the achievement according to the research's result that had been done by (Bawaneh, 2011) that said that information technology supports the learning process in the education world. Many efforts are done by an educational institute in increasing the quality of education and one of them is by doing an investigation in information technology. According to (Carrillo et al., 2012) the development of information technology rapidly gives significant impacts on the education world. In the learning process, the use of IT can increase the students' cognitive abilities that are hoped to impact their academic achievements. According to Savage (2009) IT users gives great impacts on developing the learning process such as the Internet, wireless, tablet computer, and the other IT developments that cause changes in the learning process of a university. According to Khan (2009), the use of IT in the learning process can help the students to be more effectively involved in learning and make it easy for the students to understand the course material that firstly unable to be understood. This use of information technology is hoped to lead to some things that support the academic process in the university, so it can increase the students' achievements in their studies.

According to the explanation above, this research aims to know whether there is a relationship between moral behavior, interaction with the community, and the impacts

International Journal of Educational Best Practices (IJEBP)

Vol. 4 No. 2 October 2020

ISSN: 2581-0847

DOI: $10.32581 /$ ijebp.v4n2.p18-32 
of technology on education which is about the index achievements of the students in Flores University or not.

\section{RESEARCH MODEL}

The research model in this research can be seen in Image 1. There are three independent variables and one dependent variable. The independent variables in this research are the impacts of information technology on education, the interaction with the community, and moral behavior. Then the dependent variable is the progress of index achievements.

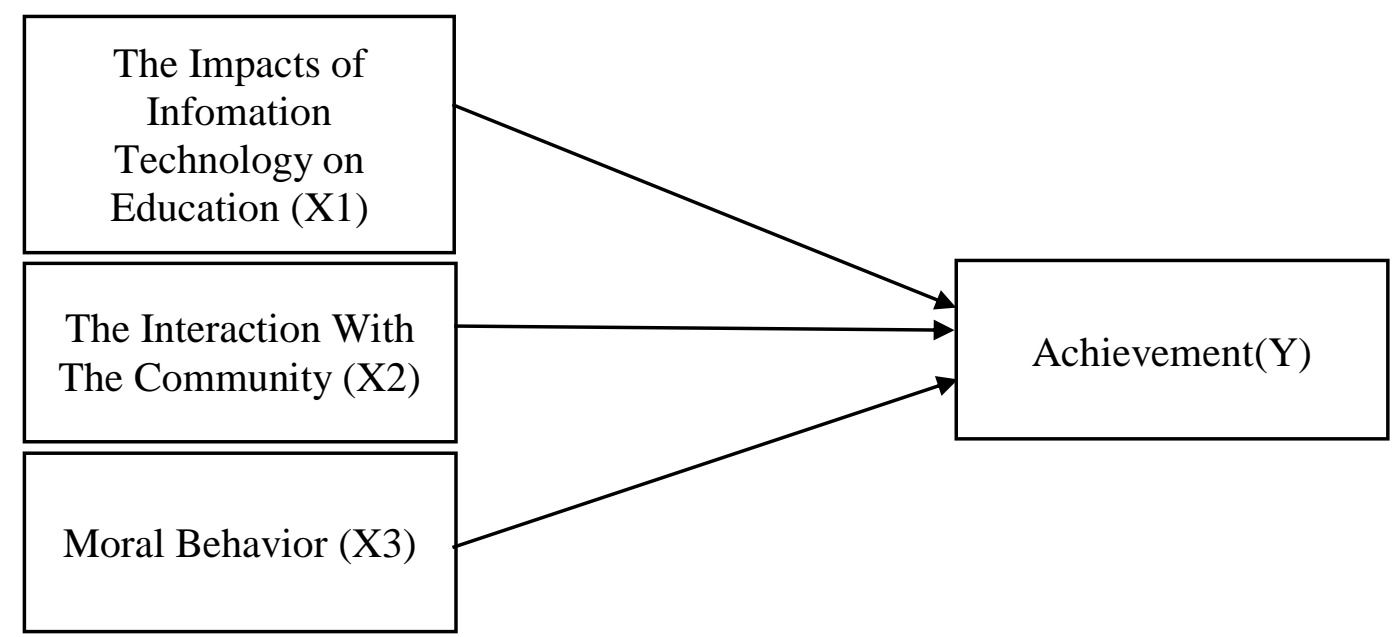

Image 1: Research structure

\section{HYPOTHESIS}

The hypothesis in this research that can be seen in Image 1 such as:

1. The variable of information technology's impacts on education influences achievement.

2. The variable of interaction with the community influences achievement.

3. The variable of moral behavior influences achievement.

\section{RESEARCH METHOD}

The method in this research is the survey method with a quantitative approach. This research aims to know whether there is a relationship between moral behavior, interaction with the community, and the impacts of technology on education which is about the index achievements of the students in Flores University or not. 


\section{The Method of Sampling}

The population in this research are the students from four program studies at Flores University such as Information System, Management, Accountant, and Economy Development. Because of the number of population, it is not possible to study or research all populations, that is why the students in the fourth semester of the educational year of 2019/2020 are chosen for being the samples.

The technique of sampling that will be used in this research is Simple Random Sampling (Meng, 2013). The number of all population is 124 students. The samples are calculated by the Slovin formula approach (Tejada and Punzalan, 2012), so it makes the samples for this research are 95 students.

\section{The Method of Data Collection}

The data for this research the type of primary data. Primary data is the source of research data that is gained directly from the original source (Hasibuan, 2007). For collecting the data, questionnaires are used. The questions for the questionnaire are filled with variable gauge items in the form of question lists and the questions that are used in the research model. the form of this questionnaire is a type of closed questionnaire which means the questions are possible to be answered openly but still keep it secretly. Next, the questionnaires are given to some students in the fourth semester in the academic year of 2019/2020 at the four study programs in Flores University such as Information System, Management, Accountant, and Economic Development.

\section{The Method of Data Analysis}

The technique of data analysis in this research is the Pearson Product Moment Correlation. For analyzing the data in this research Statistical Product and Service Solution (SPSS) 22 for Window is used (Pramesti, 2014). There are some tests levels in this research, such as:

First: the test of the instrument's quality as a good measurement and able to give the clear and right information if they are fulfilled, the criteria of the question for the measurement are valid and reliable. The test that is used to test the quality is the quality and reliability test (Chan and Indris, 2017). 
Second: the classic assumption test is done by testing the quality of quality data. The classic assumption test in this research includes a multicollinearity test, autocorrelation test, heteroscedasticity test, and linearity test (Suliyanto, 2011).

Third: Simultaneous test (F Test) is used to know whether there are influences between independent variables to dependent variables. The basis of making decisions in the $\mathrm{F}$ Test according to significant value (Sig) from Anova Output is: if the Sig value $<0,05$ the hypothesis will be accepted. Meanwhile if the Sig value $>0,05$, simultaneity does not influence the achievement (Y) (Ghozali, 2018).

Forth: Determination Coefficient Test $\left(\mathrm{R}^{2-}\right)$ is used to predict how much the contribution of Independent variables influences the dependent variable. The determination coefficient value is zero or one. The value that is closed to one means the independent variables give almost all needed information to predict the dependent variables. Meanwhile, the small value of the determination coefficient test means the abilities of independent variables to explain the variant of the dependent variable are limited (Ghozali, 2018).

Fifth: A partial test (T-Test) is used to show how far one of the independent variables individually explains the dependent variable (Ghozali, 2018). The basic in decision making of T-Test based on Significant Value (Sig.) that are: If the Significant value (Sig.) < probability 0,05 , then there is an impact or influence of free variables $(\mathrm{X})$ to the bound variable (Y) or the hypothesis are accepted. If the Significant value (Sig.) > probability 0,05 , then there is no influence of the free variable $(\mathrm{X})$ to the bound variable (Y) or the hypothesis is rejected.

\section{RESULT}

\section{The Test of Instrument Quality}

Validity Test

A validity test is used to measure whether a questionnaire is able to use or not. A questionnaire is valid if the questions can show what is measured by that questionnaire. The validity testing is by using the correlation product-moment technique. From the result of data analysis, are the result of the Validity test:

Table 1: The Result of Validity Test

\begin{tabular}{cccc}
\hline No Item & $\begin{array}{c}\text { Corrected Item- } \\
\text { Total Correlation }\end{array}$ & rtable Information \\
\hline
\end{tabular}

International Journal of Educational Best Practices (IJEBP)

Vol. 4 No. 2 October 2020

ISSN: 2581-0847

DOI: $10.32581 /$ ijebp.v4n2.p18-32 


\begin{tabular}{llll}
\hline X1.1 & 0.605 & 0.202 & Valid \\
X1.2 & 0.706 & 0.202 & Valid \\
X1.3 & 0.779 & 0.202 & Valid \\
X1.4 & 0.652 & 0.202 & Valid \\
X1.5 & 0.718 & 0.202 & Valid \\
X1.6 & 0.688 & 0.202 & Valid \\
X1.7 & 0.659 & 0.202 & Valid \\
X1.8 & 0.729 & 0.202 & Valid \\
X1.9 & 0.726 & 0.202 & Valid \\
X1.10 & 0.684 & 0.202 & Valid \\
X1.11 & 0.713 & 0.202 & Valid \\
X1.12 & 0.664 & 0.202 & Valid \\
X1.13 & 0.722 & 0.202 & Valid \\
X1.14 & 0.641 & 0.202 & Valid \\
X1.15 & 0.682 & 0.202 & Valid \\
X2.1 & 0.686 & 0.202 & Valid \\
X2.2 & 0.641 & 0.202 & Valid \\
X2.3 & 0.719 & 0.202 & Valid \\
X2.4 & 0.748 & 0.202 & Valid \\
X2.5 & 0.753 & 0.202 & Valid \\
X2.6 & 0.707 & 0.202 & Valid \\
X2.7 & 0.761 & 0.202 & Valid \\
X2.8 & 0.752 & 0.202 & Valid \\
X2.9 & 0.777 & 0.202 & Valid \\
X2.10 & 0.727 & 0.202 & Valid \\
X2.11 & 0.738 & 0.202 & Valid \\
X2.12 & 0.700 & 0.202 & Valid \\
X2.13 & 0.763 & 0.202 & Valid \\
X2.14 & 0.625 & 0.202 & Valid \\
X2.15 & 0.656 & 0.202 & Valid \\
X3.1 & 0.648 & 0.202 & Valid \\
X3.2 & 0.652 & 0.202 & Valid \\
X3.3 & 0.700 & 0.202 & Valid \\
X3.4 & 0.824 & 0.202 & Valid \\
X3.5 & 0.705 & 0.202 & Valid \\
X3.6 & 0.791 & 0.202 & Valid \\
X3.7 & 0.765 & 0.202 & Valid \\
X3.8 & 0.701 & 0.202 & Valid \\
X3.9 & 0.704 & 0.202 & Valid \\
X3.10 & 0.646 & Valid \\
X3.11 & 0.731 & Valid \\
X3.12 & 0.780 & Valid \\
X3.14 & & &
\end{tabular}




\begin{tabular}{llll}
\hline X3.15 & 0.701 & 0.202 & Valid
\end{tabular}

The validity test results on Table 1 show that all questionnaire items of three variables are valid because all those questionnaire items have the values of Corrected item-total Correlation that are more $>$ from the rtable which is about 0,2 .

\section{Reliability Test}

A reliability test is a measurement that reliable if the measurement shows the $\mathrm{s}$ consistent result from time to time. In the Reliability test correlation, the Product Moment technique is used. Below is the result:

Table 2: The Result of Reliability Test

\begin{tabular}{lcc}
\hline \multicolumn{1}{c}{ Variable } & $\begin{array}{c}\text { Cronbach's } \\
\text { Alpha }\end{array}$ & Information \\
\hline $\begin{array}{l}\text { The Impact of Information } \\
\text { Technology on Education } \\
\text { (X1) }\end{array}$ & 0.933 & Reliable \\
$\begin{array}{l}\text { The Interaction With The } \\
\text { Community (X2) }\end{array}$ & 0.943 & Reliable \\
The Mora Behavior (X3) & 0.942 & Reliable
\end{tabular}

Table 2 shows that all items of each variable are reliable because the Cronbach's Alpha value is $>0,6$.

\section{The Classic Assumption Test}

\section{The Multicollinearity Test}

The multicollinearity test is used to test whether there is a correlation between independent variables in the regression model or not. There will be no correlation between the free variable when the regression model is well. For detecting the multicollinearity case in regression models, there are 2 ways used: (1) According to Tolerance. If the tolerance value is $>0,10$, it means that there is multicollinearity. Meanwhile, if the tolerance value is $<0,10$, it means that multicollinearity does not happen in the regression model, and (2) according to VIF (Variance Inflation Factor). If the VIF is $<10,00$, means that there is multicollinearity meanwhile if the VIF $>10,00$, the multicollinearity does not in the regression model. the multicollinearity test is by using SPSS. The results can be seen in the table below: 
Table 3: The Result of Multicollinearity Test

\begin{tabular}{|c|c|c|c|c|c|c|c|c|}
\hline \multicolumn{9}{|c|}{ Coefficients } \\
\hline \multirow{2}{*}{\multicolumn{2}{|c|}{ Model }} & \multicolumn{2}{|c|}{$\begin{array}{c}\text { Unstandardized } \\
\text { Coefficients }\end{array}$} & \multirow{2}{*}{$\begin{array}{c}\begin{array}{c}\text { Standardized } \\
\text { Coefficients }\end{array} \\
\text { Beta }\end{array}$} & \multirow[t]{2}{*}{$\mathbf{t}$} & \multirow[t]{2}{*}{ Sig. } & \multicolumn{2}{|c|}{$\begin{array}{c}\text { Collinearity } \\
\text { Statistics }\end{array}$} \\
\hline & & B & $\begin{array}{l}\text { Std. } \\
\text { Error }\end{array}$ & & & & Tolerance & VIF \\
\hline \multirow[t]{4}{*}{1} & (Constant) & -.262 & .083 & & 3.175 & .002 & & \\
\hline & $\begin{array}{l}\text { The Impact of } \\
\text { Information } \\
\text { Technology on } \\
\text { Education }\end{array}$ & .685 & .075 & .933 & 9.168 & .000 & .139 & 7.169 \\
\hline & $\begin{array}{l}\text { The Interaction } \\
\text { with the } \\
\text { Community }\end{array}$ & .129 & .120 & .069 & 1.077 & .284 & .347 & 2.878 \\
\hline & $\begin{array}{l}\text { The Moral } \\
\text { Behavior }\end{array}$ & -.053 & .082 & -.062 & -.641 & .523 & .152 & 6.572 \\
\hline
\end{tabular}

a. Dependent Variable: Achievement

Based on Table 3, the tolerance value for each variable is $>0,10$. Meanwhile, the VIF of each variable is $<10,00$, it shows that for each variable in Tolerance value and VIF, the multicollinearity does not happen in the regression model.

\section{TheAutocorrelation Test by using Run Test}

The autocorrelation test is used to test the linear regression model according to know if there is a confounding error correlation in period $t$ with the mistakes in period $t-1$ (before) or not. If there is a correlation, it will be named an autocorrelation problem. The basics to decide in Run test testing are: If the Asymp. Sig. ( 2 tailed) is $<0,05$ then there is autocorrelation, meanwhile if the Asymp. Sig ( 2 tailed) is $>0,05$ then there is autocorrelation. The correlation test is by using SPSS. are the result of the Autocorrelation test: 
Table 4: The Result of Autocorrelation Test

\begin{tabular}{|l|r|}
\hline \multicolumn{2}{|c}{ Runs Test } \\
\hline Test & $\begin{array}{c}\text { Unstandardized } \\
\text { Residual }\end{array}$ \\
Cases < Test Value & .00144 \\
Cases >= Test Value & 47 \\
Total Cases & 48 \\
Number of Runs & 95 \\
Z & 42 \\
Asymp. Sig. (2-tailed) & -1.340 \\
\hline
\end{tabular}

a. Median

Based on Table 4, the values of Asymp. Sig ( 2 tailed) is $0,180>0,05$, it means that there is no autocorrelation.

\section{Heteroscedasticity Test}

The heteroscedasticity test means the classic assumption test to test whether or not the unsimilarity variant from the first observation residual to another observation residual one. If there are some points in the scatterplots graphic that spread randomly at 0 in the $\mathrm{Y}$ and can be concluded that there is heteroscedasticity. The Heteroscedasticity test is by using SPSS. The results can be seen in the image below: 


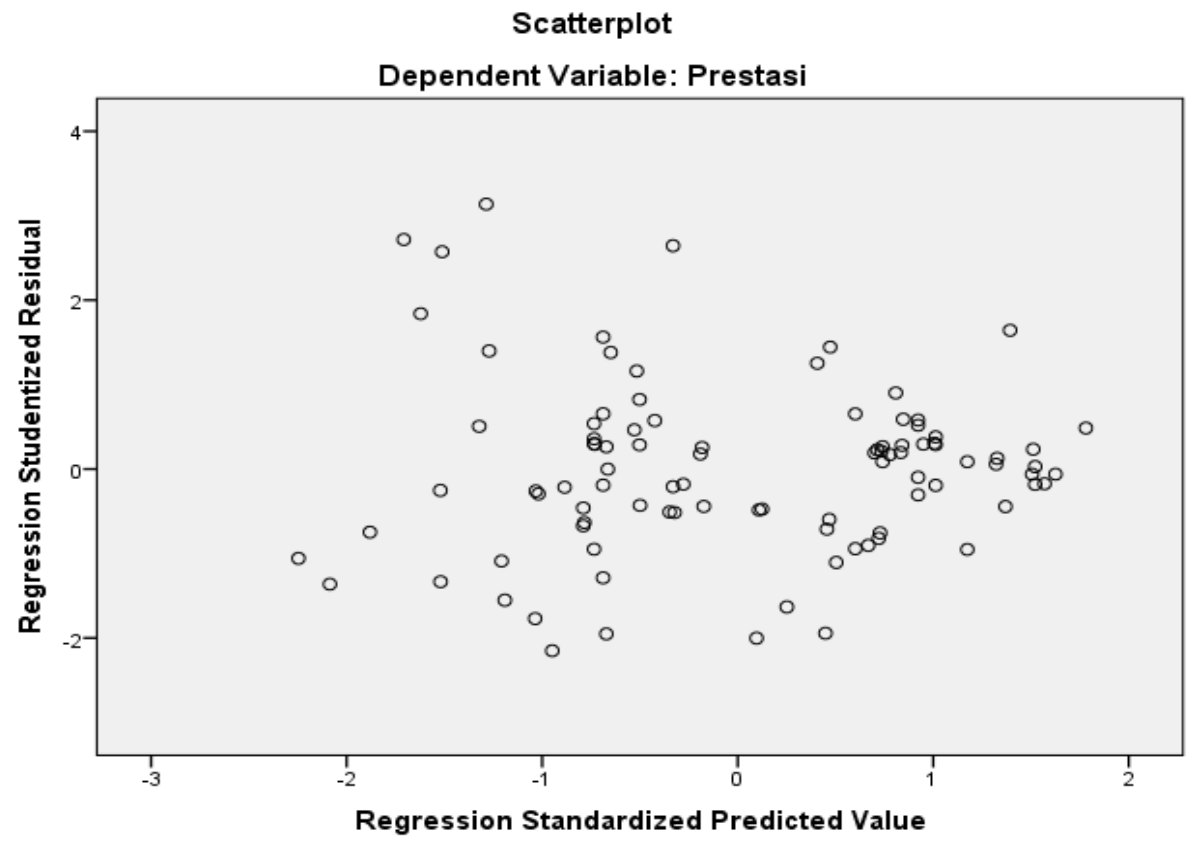

Image 2: Heteroscedasticity Test Result

Based on Image 2, some points spread randomly at 0 on $\mathrm{Y}$, and the spreading of those data points is not patterned, so the conclusion is no heteroscedasticity problem happened.

\section{Linearity Test}

The Linearity test is the classic assumption test to know whether or not the regression model can be called linear. The basic in decision making of linearity test comparing the value of significant (Sig.) with 0,05 are: If the Deviation from linearity Sig. Is $<0,05$ means that there is no significant linear connection between the independent variable and the dependent variable. SPSS is used to test the linearity. In the table below are the results:

Table 5: The Result of Linearity Test

Deviation from Linearity

\begin{tabular}{|l|c|c|c|c|c|}
\hline & $\begin{array}{c}\text { Sum of } \\
\text { Squares }\end{array}$ & df & $\begin{array}{c}\text { Mean } \\
\text { Square }\end{array}$ & F & Sig. \\
\hline $\begin{array}{l}\text { Achievement } * \\
\text { The Impact of } \\
\text { Information } \\
\text { Technology on } \\
\text { Education }\end{array}$ & 136.687 & 23 & 5.943 & .974 & .507 \\
\hline
\end{tabular}

International Journal of Educational Best Practices (IJEBP)

Vol. 4 No. 2 October 2020

ISSN: 2581-0847

DOI: 10.32581/ijebp.v4n2.p18-32 


\begin{tabular}{|l|r|r|r|r|r|}
$\begin{array}{l}\text { Achievement* The } \\
\text { interaction in } \\
\text { Community }\end{array}$ & 885.782 & 24 & 36.908 & 2.849 & .084 \\
\hline $\begin{array}{l}\text { Achievement * } \\
\text { The Moral } \\
\text { Behavior }\end{array}$ & 347.592 & 24 & 14.483 & 1.666 & .062 \\
\hline
\end{tabular}

Table 5 shows that the significant value (Sig.) gets the Deviation value from Linearity Sig. Each variable is $>0,05$, so the conclusion is there is a linear connection between the variable of information technology's impact on education (X1), The interaction with the community (X2), and the moral behavior (X3) to the Achievement variable (Y) by seeing the index of Cummulative Achievement (IPK).

\section{The Simultaneous Test (F Test)}

The stimulant test (F Test) is used to know whether there is co-influence between independent variables (The impact of information technology on education, the interaction with the community, and the moral behavior) to the dependent variable (Achievement Index) The basic of making a decision in F Test based on significant (Sig.) value of Anova Output, that is: If the Sig. The value is < 0,05, then the hypothesis is accepted. It means that the impact of information technology on education (X1), the interaction in the community (X2), and the moral behavior (X3) simultaneous influence the achievement (Y). SPSS is used to test the F Test. The result can be seen in the table below:

Table 6: The Result of F Simultaneous Test

ANOVA

\begin{tabular}{|l|l|r|r|r|r|r|}
\hline \multicolumn{2}{|c|}{ Model } & $\begin{array}{c}\text { Sum of } \\
\text { Squares }\end{array}$ & Df & $\begin{array}{c}\text { Mean } \\
\text { Square }\end{array}$ & \multicolumn{1}{c|}{ F } & \multicolumn{1}{c|}{ Sig. } \\
\hline \multirow{3}{*}{1} & Regression & 1.552 & 3 & .517 & 20.524 &, $000^{\mathrm{b}}$ \\
\cline { 2 - 7 } & Residual & .235 & 91 & .003 & & \\
\cline { 2 - 7 } & Total & 1.787 & 94 & & & \\
\hline
\end{tabular}

a. Dependent Variable: achievement

b. Predictors: (Constant), The Moral Behavior, The interaction with

Community, The Impact of Information Technology in Education.

Based on the Anova output table, it is known that the Significant (Sig.), the significant value (Sig.) is 0,000 . Because of the Sig. Value is 0,000 and $<0,05$, it shows that the hypothesis is accepted or the impact of information technology in education (1), the interaction with the community (X2), and the moral behavior (X3) simultaneously influence. 


\section{The Determination Coefficient Test}

The symbol of the determination coefficient is $\mathrm{R}^{2}$ that is used to predict and see how much the contribution of influence is being given by independent variables simultaneously to the dependent variable. The condition that must be fulfilled is the result of the $\mathrm{F}$ test that significant value which means the independent variables simultaneously influence the dependent variable. Based on the result of the F test, the significant value (Sig.) is 0,000 , because of the Sig. Value is 0,000 that $<0,05$, it shows that independents variables simultaneously influence the dependent variable. The next one is by seeing the presentation $(\%)$ of influence that is given by independent variables to the dependent variable simultaneously by seeing the value of $\mathrm{R}$ Square on the summary model table. SPSS is used to analyze the data and the result can be seen in the table below:

Table 7: The Result of Determination Coefficient Test $\left(\mathbf{R}^{2}\right)$

\begin{tabular}{|l|r|r|r|c|}
\hline Model & R & R Square & $\begin{array}{c}\text { Adjusted } \\
\text { R Square }\end{array}$ & $\begin{array}{c}\text { Std. Error } \\
\text { of the } \\
\text { Estimate }\end{array}$ \\
\hline 1 &, $932^{\mathrm{a}}$ & .869 & .864 & .05080 \\
\hline
\end{tabular}
a. Predictors: (Constant), Moral Behavior, Interaction with
community, the impact of information technology in education
b. Dependent Variable: Achievement

Based on table 7, the coefficient determination or R Square is 0,0869 . R Square is 0,869 or $86 \%$. It shows that the variable of information technology's impact in education (X1) variable, the variable of interaction with the community (X2), and the variable of moral behavior (X3) simultaneity influence the achievement (Y), can be seen from the index of cumulative achievement (IPK) is $86,9 \%$. Meanwhile, 13,1\% that is left influenced by other variables that unresearched in this research.

\section{Hypothesis Test}

Partial Test (T-Test) 
T-test aims to know whether the independent variables partially influence the dependent variable or not. The basics of decision making in the T-test based on Significant (Sig) value are: If the Significant (Sig.) value is < probability 0,05 the influence of free variable $(\mathrm{X})$ to the bound variable $(\mathrm{Y})$ or the hypothesis is accepted. if the value of significant (Sig.) is > probability 0,05 means that the free variables (X) do not influence the bound variable or the hypothesis is denied. SPSS is used in this test and the result can be seen in the table below:

Table 8: The Result of Partial Test (T-Test)

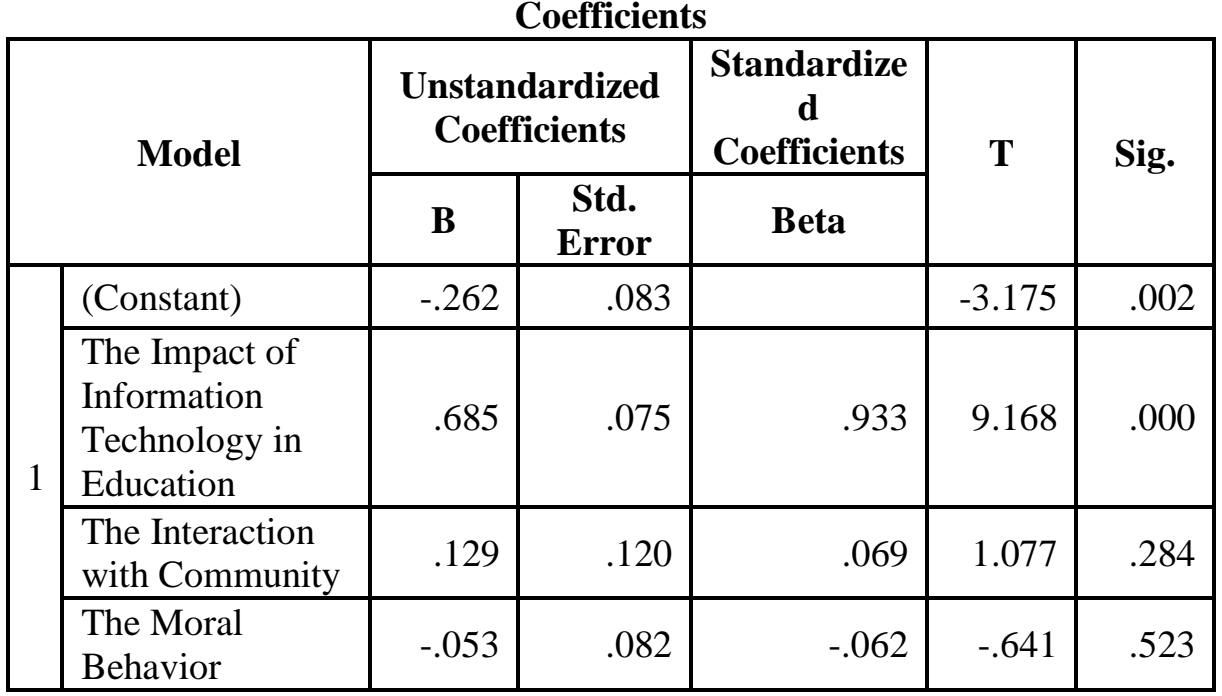

a. Dependent Variable: Achievement.

Based on Table 8, hypothesis results are known as below:

1) The first t-test to know whether the impact of information technology in education (X1) influences achievement (Y). Based on the Significant value (Sig.), the variable of information technology's impact (X1) is $0,000<0,05$, so the conclusion is the first hypothesis accepted. It means that there is a positive impact of information technology (X1) on achievement (Y). It shows that the use of information technology can help the students in doing their assignments. They can also access the electronic media that can make the gaining of course material easier, and information technology can be used as the learning media for the students in supporting their achievement and satisfying, so it can positively impact or influence the students' achievements.

2) The second t-test aims to know whether the interaction with the community (X2) influences the achievement (Y). Based on the Significant value (Sig), the variable of the interaction with the community (X2) is 0,284. Because of the Sig. 0,284 > the probability of 0,05 , the conclusion is the second hypothesis rejected. It means that the interaction with the community (X2) does not influence the achievement (Y).

3) The third test is used to know whether moral behavior (X3) influences achievement (Y). Based on the Significant value (Sig.), the variable of moral behavior is 0,523 . 
because of the Sig. Value $0,523>$ the probability of 0,05 , the conclusion is the third hypothesis cannot be accepted or rejected. It means that moral behavior (X3) does not influence the achievement (Y).

\section{CONCLUSION}

After the researchers did the test and analyzed the data in this research, the researchers can conclude some important things. The first is the variable of information technology's impact on Education influences positively the achievement, it can be seen from the Design. Value, where the variable of information technology's impact is 0,000 $<$ the probability 0,05 , so the hypothesis is accepted. the second one is the variable of interaction with the community does not influence the achievement because of the Sig. Valur from the variable of interaction with the community (X2) is $0,284>0,05$, so this hypothesis is denied. The third is the variable of moral behavior does not influence the achievement variable because the significant value (Sig.) from the variable of moral behavior (X3) is $0,523>0,05$, so the hypothesis is also denied. It shows that the good and right use of information technology will increase students' achievements, meanwhile the interaction with the community, and moral behavior as the complement to support the students in reaching their good achievements in Flores University.

\section{REFERENCES}

Abdul Kadir. (2014). Pengenalan Sistem Informasi Edisi Revisi. In Edisi Revisi.

Bawaneh, S. S. (2011). Does using computer technology improve students ' performance? Evidence from a management accounting course. Journal of Business.

Carrillo, P. E., Onofa, M., \& Ponce, J. (2012). Information Technology and Student Achievement: Evidence from a Randomized Experiment in Ecuador. SSRN Electronic Journal. https://doi.org/10.2139/ssrn.1818756

Chan, L. L., \& Idris, N. (2017). Validity and Reliability of The Instrument Using Exploratory Factor Analysis and Cronbachâ $\square \mathrm{TM}_{\mathrm{S}}$ alpha. International Journal of Academic Research in Business and Social Sciences, 7(10), 400-410. https://doi.org/10.6007/ijarbss/v7-i10/3387

Ghozali, I. (2018). Aplikasi Analisis Multivariate dengan Program IBM SPSS. Yogyakarta: Universitas Diponegoro. In (Edisi 9). Semarang: Badan Penerbit Universitas Diponegoro. 
Hasibuan, Z. A. (2007). Metodologi Penelitian Pada Bidang Ilmu Komputer Dan Teknologi Informasi. Konsep, Teknik, Dan Aplikasi.

Khan, M. (2009). Effects of Information Technology Usage on Student Learning - an Empirical Study in the United States. International Journal of Management.

Meng, X. (2013). Scalable simple random sampling and stratified sampling. 30th International Conference on Machine Learning, ICML 2013, 28(PART 2), 15681576.

Pramesti, G. (2014). Kupas Tuntas Data Penelitian dengan SPSS 22. PT Elex Media Komputindo.

Savage, S. (2009). The effect of information technology on economic education. Journal of Economic Education. https://doi.org/10.1080/00220480903237901

Suliyanto. (2011). Uji Asumsi Klasik Normalitas. Ekonometrika Terapan: Teori \& Aplikasi Dengan SPSS.

Tejada, J., \& Punzalan, J. (2012). On the misuse of Slovin's formula. The Philippine Statistician, 61(1), 129-136. 